Background: Breast cancer is not only a medical but also a social problem due to the emotional significance attached to female breasts (attribute of womanhood, symbol of maternity) and the fear of the mutilating procedure of mastectomy. One of the factors that influence one's ability to cope with the difficult situation resulting from the illness as well as with stress is sense of coherence (SOC). SOC allows one to understand the relationship between the support received by an ill person and their health. A high level of SOC allows patients to see the meaning in life, to believe in life's order and predictability, which in turn makes them want to be healthy and fully functional. One of the external resources that influence one's health is social support. The purpose of the study was to assess SOC and the meaning of social support received by women after mastectomy as a determinant of regaining optimum health. Material and methods: The study was conducted at the breast disease ward of the Oncology Centre in Bydgoszcz during which 76 women after mastectomy due to cancer were tested. The SOC level was assessed using Antonovsky's SOC-29 Questionnaire, whereas the level of social support was measured using the Kmiecik-Baran Scale. Results: The study shows that the level of manageability and meaningfulness varies among women who underwent mastectomy, whereas the level of their comprehensibility and global level of SOC is the same for all the patients. These differences could be observed, however, in relation to the level of social support they received, especially the appraisal and instrumental support.

Conclusions: The study will enable better understanding of psychosocial problems of women after mastectomy, whereas recognition of their needs in the scope of support will allow us to compensate for the lack of it and as a result will enable these women to regain optimum health.

Key words: breast cancer, social support, sense of coherence (SOC).

\section{Sense of coherence (SOC) and social support received by women after mastectomy}

\author{
Krystyna Kurowska, Barbara Kaczorek
}

Department and Faculty of Nursing Pedagogy and Didactics at CM UMK Torun

\section{Background}

The world today is a world of great progress, changes taking place in our civilization and a new lifestyle. Unfortunately, however, despite development made in medicine, knowledge of principles of prevention, modern methods of diagnostics and treatment, we are aware that due to continued development of civilisation, ongoing industrialisation and urbanisation there is a constant growth of factors posing immediate danger to human life and health. One of the most common and the most dangerous diseases of today is cancer of various kinds. The most common cancer suffered by women is breast cancer. It constitutes $17 \%$ of all malignant tumours suffered by women in Poland [1]. Diagnosis of cancer means for many women a life threat on the one hand and mutilation, deprivation of physical attributes of femininity and marriage on the other. Social support is one of the most studied resources of stress tolerance, especially tolerance to stress associated with the disease [2]. Support for women who had their breasts removed due to cancer and a high level of SOC are crucial factors that help the patients to return to their everyday life. The purpose of the study was to examine the level of sense of coherence in women after mastectomy and the importance of social support they received and expected to receive as an indicator in their return to optimal health.

\section{Material and methods}

The study presented here is part of a bigger project the aim of which was analysis of life quality of people diagnosed with cancer. The study was conducted from November 2007 to November 2008 on a group of 76 women after mastectomy due to cancer who were hospitalised at the breast disease ward of the Oncology Centre in Bydgoszcz. The study was conducted with the consent of the Bioethical Committee of L. Rydygier Collegium Medicum in Bydgoszcz (KB/574/2007). In the study Antonovsky's Sense of Coherence Scale (SOC-29) and the Kmiecik-Baran Social Support Scale and a self-made questionnaire, which concerned various aspects of life, were used. To describe the variables descriptive statistics (arithmetic average, minimum, maximum, and standard deviation) and distribution of variables were used. The differences were estimated on the basis of single-factor analysis of variance, whereas relationships were examined with the use of Pearson's linear correlation coefficient. The test values fulfilling the condition that $p<0.05$ are considered as statistically significant. All the analyses were conducted using the statistical package STATISTICA ver. 6.0.

\section{Results}

Data analysis shows that the average age of respondents was 54 years. The majority of them had secondary education (43.42\%) or higher education (31.57\%). Most of them were married (73.68\%) and had children (93.42\%). $34.21 \%$ lived in a county town and the same number of respondents lived in the In most cases (71.05\%) women admitted that there were other instances 
of cancer in their families. All the test subjects had undergone the operation of breast amputation and in $77.64 \%$ mastectomy had been conducted six to twelve months ago. None of the women were treated immunologically and radio and chemotherapy was performed on $44.7 \%$ of all the respondents. The majority of women considered their health to be in a good condition although there was some health trouble (64.15\%). Physical discomfort during performance of everyday activities connected with self-care was experienced by $56.7 \%$ of all the respondents. The fact of breast amputation had a negative influence on the intimate life of $72 \%$ of all the surveyed women, $30 \%$ thought about recurrence of the disease and $21 \%$ feared subsequent doctor appointments. Thirty-four percent accepted their appearance and there was no decrease in the sense of self-esteem, and $82 \%$ said that breast reconstruction was not of crucial importance to them. More than $82 \%$ informed their relatives about the details regarding the procedure (mastectomy). Ninety-two percent of the respondents said that they could count on their families after the mastectomy and 96.05\% reported that the number of friends stayed the same. $51.31 \%$ of all the women were looking for contact with people who had undergone the same operation, for example in the 'Amazon Club' which associates women after mastectomy. The majority of the respondents claimed that they did not need the assistance of a psychologist (76\%) and $47.36 \%$ considered themselves as people with a rather optimistic approach towards life.

In order to evaluate sense of coherence of women who had their breast removed due to cancer an Orientation to
Life Questionnaire (SOC-29) was used. It contains 29 questions relating to specific aspects of sense of coherence, namely to comprehensibility, manageability, and meaningfulness. The distribution of the results in Table 1 shows that the SOC level of women after mastectomy varies in the scope of individual components, i.e. sense of manageability and meaningfulness, but they were the same in the scope of comprehensibility and the global SOC level. As far as global SOC level is concerned the average level was rather low, since it only amounted to 117.19 and it was similar to average values of people with oncological diseases.

The types of social support listed in Table 2 were included in the Kmiecik-Baran Questionnaire which tested social support (appraisal, emotional, informational, instrumental). The arithmetic average shows that the highest level of support received by the respondents was in informational support (21.73\%). Surprisingly, the level of emotional support was relatively high too (19.57\%), although based on theory we assumed that the level of this kind of support would be the lowest. A noticeably lower level of support was received in instrumental support (16.56\%) and appraisal support (15.48\%). There was high differentiation among the women regarding the level of instrumental and appraisal support they received.

In Table 3 the relationship between SOC level together with its components and components of social support has been determined. In this table coefficients of Pearson's linear correlation have been listed. Of importance is the fact that appraisal support was related statistically significantly with all the SOC subscales (comprehensibility, manageabili-

Table 1. Descriptive statistics of sense of coherence (SOC) and its components

\begin{tabular}{|lccccc|}
\hline SOC components & N important & Mean & Minimum & Maximum & Standard deviation \\
\hline Comprehensibility & 76 & 46.09 & 11 & 66 & 6.92 \\
\hline Manageability & 76 & 37.81 & 10 & 60 & 7.09 \\
\hline Meaningfulness & 76 & 33.28 & 29 & 46 & 5.62 \\
\hline Global SOC & 76 & 117.19 & 172 & 16.05 \\
\hline
\end{tabular}

Table 2. Descriptive statistics of social support

\begin{tabular}{|lccccc}
\hline Kind of support & N important & Mean & Minimum & Maximum & Standard deviation \\
\hline Valuative & 76 & 15.48 & 6 & 28 & 3.54 \\
\hline Emotional & 76 & 19.57 & 21.73 & 15 & 24 \\
\hline Informational & 76 & 16.56 & 9 & 27 & 30 \\
\hline Instrumental & 76 & & 3.49 & 38 \\
\hline
\end{tabular}

Table 3. Relationship between the sense of coherence (SOC) level and social support

\begin{tabular}{|c|c|c|c|c|}
\hline & Valuative & Emotional & Informational & Instrumental \\
\hline Comprehensibility & $0.40^{*}$ & -0.03 & $0.37^{\star}$ & 0.18 \\
\hline Manageability & $0.48^{*}$ & -0.07 & $0.45^{*}$ & $0.33^{*}$ \\
\hline Meaningfulness & $0.33^{*}$ & $0.41^{\star}$ & $0.24^{\star}$ & $-0.31^{\star}$ \\
\hline Global SOC & $0.43^{*}$ & -0.15 & $0.33^{*}$ & $0.24^{*}$ \\
\hline
\end{tabular}


ty, meaningfulness and the global SOC level) and the relationship was consistent and average. The higher the level of comprehensibility, manageability, and meaningfulness, the higher was the perception of appraisal support. As far as emotional support is concerned, one statistically significant relationship at the level of 0.41 could be observed, which means that also in this case it formed a consistent and average relationship with meaningfulness, i.e. the higher the meaningfulness the higher the emotional support received. Informational support was also related to all the subscales of the sense of coherence and the global SOC. What is important, however, is the fact that in the case of instrumental support and meaningfulness the relationship was weak, while in the case of other subscales and the global sense of coherence the relationship was consistent but average. As far as instrumental support is concerned there were no statistically significant relationships between this support and comprehensibility, while a statistically significant relationship existed between instrumental support and manageability. It was an average consistent relationship and weak in relation with the global SOC. Further on, the relationship was consistent, while surprisingly enough it was an opposite though statistically significant relationship with reference to meaningfulness. This could mean that women with a lower level of meaningfulness receive greater instrumental support.

Analysis of demographic data calculated on the basis of single-factor analysis of variance (F-test) shows that neither SOC level nor the level of support depended on the age of the respondents. As far as marital status is concerned, such a trend could be observed in the case of emotional support $(F=5.6981 ; p<0.0014)$. Surprisingly enough, single women (widows or divorced) received a higher level of emotional support from other people. Residing with specific persons was a factor that differentiated manageability $(F=5.0072$; $p<0.0091)$, meaningfulness $(F=5.6959 ; p<0.0050)$ and the global SOC level $(F=6.2745 ; p<0.0030)$. No difference of this kind could be observed in the case of appraisal support. Women living by themselves had significantly lower levels of manageability (30.14), meaningfulness (26.85) and global SOC (98.14). Education turned out to be a factor that differentiated meaningfulness $(F=3.1619 ; p<0.0296)$, appraisal support $(F=3.6116 ; p<0.0172)$ and informational support $(F=4.4840 ; p<0.8861)$. Women with the lowest degree of education (primary education) showed a significantly higher level of meaningfulness (40), while at the same time they received a much lower level of appraisal support (11) and informational support (18). Employment was not a factor differentiating the SOC and social support levels. Place of residence differentiated manageability $(F=3.1686$; $p<0.0479)$, emotional support $(F=5.9757 ; p<0.0039)$, and instrumental support $(F=3.6560 ; p<0.0306)$. Women living in larger cities had a rather high level of manageability (39.58) and the lowest level of emotional support (18.25), whereas as far as instrumental support is concerned women living in the country received the lowest level of this support (15.11). It can be observed that material situation did not differentiate the SOC level and the level of individual types of social support.

Further on, variables connected with the disease were analysed. Other cases of cancer in the family constituted a factor that significantly differentiated the SOC level
$(F=0.3418 ; p<0.7115)$ or the level of received support. It could be observed that the time that had passed since the operation and the operation as such did not differentiate the global SOC level and social support in any way whatsoever. Radiotherapy was statistically significant and differentiated manageability $(F=7.9860 ; p<0.0060)$, meaningfulness $(F=4.1107 ; p<0.0462)$ and the global SOC level $(F=4.8211 ; p<0.0312)$. Women who were subjected to radiotherapy showed a higher level of manageability (45.33), meaningfulness (37.66) and the global SOC level (130.66). These people had probably been ill for a longer period of time and therefore had more time to get accustomed to the disease and the level of criticality of diagnosis and treatment had already passed. Chemotherapy was not a factor that in any statistically significant way differentiated the degree of SOC and social support. Nor was evaluation of health condition, whereas the feeling of physical discomfort was a factor that differentiated the level of meaningfulness ( $F=3.2923 ; p<0.0427)$. In women who did not feel physical discomfort, a higher level of meaningfulness could be observed (34.34). The influence of amputation on the intimate life was a factor differentiating instrumental support $(F=3.0884 ; p<0.0037)$, which was higher in persons who claimed that the fact of breast amputation had a negative influence on their intimate life. Thinking about the possibility of relapse of the disease was a factor that differentiated in a significant way only instrumental support $(F=3.3481 ; p<0.0019)$. The women who thought about relapse of the disease received the highest degree of instrumental support. Fear during regular examinations in the breast cancer clinic did not differentiate either SOC or the social support received. Acceptance of one's appearance turned out to be a factor significantly differentiating comprehensibility $(F=3.4385 ; p<0.0015)$, manageability $(F=2.2693 ; p<0.0278)$ and the global SOC level $(F=2.8545$; $p<0.0066)$. The respondents who accepted their appearance more had greater comprehensibility (48.61) as well a manageability (40.73) and global SOC level (122.11). Feeling of self-esteem was a factor that differentiated instrumental support and women in whom the sense of selfesteem had changed showed a significantly lower level of instrumental support (15.41). Possibility of breast reconstruction surgery differentiated appraisal support $(F=2.9644 ; p<0.0066)$. It turns out that the possibility of breast reconstruction surgery did not have any significance in persons with a higher level of appraisal support, or in this case with greater self-esteem. Eighty-two percent of all the respondents informed their relatives about the nature of the surgery, and what is also significant, this factor had an influence on appraisal support $(F=2.5475 ; p<0.0173)$ as well. Women who informed their relatives about the nature of the operation turned out to be persons with a significantly high level of appraisal support. Surprisingly enough, however, results regarding this kind of support were also high in the case of persons relatives of whom did not know anything about the nature of the surgery they had undergone. The closest family was a factor that differentiated only informational support and not the social support as such. Informational support was greater in the case of women who could count on their families (21.86). Distant 
family also constituted a factor that only differentiated informational support $(F=4.9936 ; p<0.0284)$, which means that people who could count on their distant families received higher level of informational support (22.54). Having friends was also a differentiating factor in the case of instrumental support $(F=10.7376 ; p<0.0016)$. What is interesting, people who could not rely on their friends' support received higher level of instrumental support (18.13). Neighbours as a support group differentiated instrumental support as well $(F=9.1116 ; p<0.0034)$ and those women who could not count on their neighbours' support received a higher level of instrumental support (17.34). Looking for associations or groups associating people suffering from similar disease ('Amazon Club') was a factor differentiating the level of meaningfulness ( $F=3.4501 ; p<0.0370)$, and what is significant is the fact that looking for such an association was at the same time a factor that differentiated level of meaningfulness in such a way that the higher level of meaningfulness could be observed in those women who did not look for such a contact (34.27). It also turned out that seeking the assistance of a psychologist differentiated the level of appraisal support ( $F=2.7198 ; 0.0117$ ). Respondents who needed appraisal support demonstrated the lowest level of this support and indeed confessed that they needed it. However, this was not a linear trend, which is why a low result was obtained in the case of persons who indicated that they did not need psychological assistance. Analysis of variances shows that an optimistic attitude towards life was a factor differentiating the level of instrumental support $(F=3.0210 ; p<0.0058)$ and women with a lower level of optimism needed a higher level of such support.

\section{Discussion}

Of all the diseases it is the tumours that have the strongest influence on the human psyche. Nobody is prepared for such diseases. Life used to run a familiar route and despite all difficulties it was in some sense consistent and predictable. All of a sudden something that nobody expected has happened. It was usually other people who suffered from cancer and any thought of falling ill with this disease was immediately discarded. We have been afraid of this disease since the dawn of time; it is burdened with a strong social fear, which is why at the starting phase of treatment patients very often suffer from a mental "holocaust". It is impossible to explain in a rational way. People simply seem to have become accustomed to the thought that "cancer means death". Despite the enormous progress that has been made, especially in the early diagnosis and treatment of breast cancer, feelings related to this disease are still to be changed. Although statistics show that increasing numbers of people suffering from breast cancer live longer and that for more and more people this disease has changed from fatal to chronic and just like diabetes or hypertension it requires long-term treatment, the myth about the hopelessness of this disease still prevails [1]. People who have to face cancer, which undoubtedly is very difficult, tend to forget that in everyone there are inexhaustible resources of energy that mobilise people to reach for the final goal and to struggle for one's health and life.
According to Aaron Antonovsky, the creator of a new approach towards health, every person has a certain, more or less constant attribute called sense of coherence, which is distinctive for each of us. It is a variable that determines whether on the health-disease continuum we are closer to the health or disease pole [3]. In our earlier tests concerning the role of sense of coherence and health behaviour in the chronically ill we managed to demonstrate that the sense of coherence is an attribute that has a major influence on occurrence of illness and its course [4]. The purpose of this study was to test the SOC level and the significance of social support received by women after mastectomy. The study involved 76 women after breast amputation due to cancer whose age ranged between 28 and 78 years old, although it usually ranged between 43 and 63 years. In contemporary literature on this subject no observations have been found concerning sense of coherence and social support received by women after mastectomy, which is why it was difficult to compare the results with other studies. A large proportion of the studies were dedicated to health behaviour and life quality of women after mastectomy and sense of coherence in people suffering from various kinds of oncological diseases. Analysis of data obtained from the study shows that women after mastectomy had different SOC levels and the level of its components in the scope of two subscales, namely manageability and meaningfulness. Manageability showed far greater diversity than meaningfulness. Sense of meaningfulness showed that awareness of one's own importance and of one's own significance and the possibility to participate in decision-making processes concerning one's life was present in all of the respondents. The sense of manageability, that is the ability to make use of one's intellectual and emotional resources as well as to make use of help offered by other people and various institutions, was much stronger. This could mean that there was lack of confidence in the outside world and lack of faith that it can be predictable and repetitive. There are no indications whatsoever that women differed from one another regarding level of comprehensibility and the global SOC, which amounted to about 117 points. It was much lower than normative values submitted by Antonovsky (133-160 points) [3], whereas it was similar to the value present in people diagnosed with cancer. Women suffering from breast cancer who underwent breast amputation showed a low level of SOC since they were subjected to enormous psychological stress connected with diagnosis as well as with treatment of cancer, yet most of all with the loss of a breast, which was an attribute of femininity and motherhood. Life after mastectomy is connected with many sacrifices and is the source of much discomfort and feelings of uncertainty and as a result difficulties may arise in sustaining a high level of SOC. A study conducted by Basińska regarding the health condition of women with the risk of breast cancer and cancer of reproductive organs shows clearly that the thesis included in Antonovsky's theory stating that during disease the level of SOC, especially of comprehensibility, decreases may be considered as valid. On the other hand, the sense of meaningfulness reflects motivation to regain balance 
and positive adaptation regarding disease [5]. According to Skokowski a much lower level of global SOC and its elements in ill people than in healthy people may illustrate a disruptive influence of feelings and experiences associated with cancer and anticipation of dangers related to the operation on the orientation processes of people. With the help of their study they also proved that people suffering from lung cancer have a much lower degree of SOC [6]. The same conclusion was reached by Tuszewska on the basis of the study she conducted relating to SOC level of people suffering from ulcerative colitis [7] and by Kozak, who studied the SOC level of women with ovarian cancer [8]. On the basis of analysis of statistical data obtained from the respondents, the highest level of support received by the women was in informational and emotional support, while in theory it is claimed that the level of this support is indicated by patients as the lowest one they receive [9]. In the study conducted by Wojtyna it was suggested that receipt of emotional support is strongly connected with a lower level of distress, pain felt by the patients, and depression, and as a result it may have an influence on psychosocial adaptability to cancer [10]. The fact that women after mastectomy most often require the highest level of informational support may be confirmed by a study conducted by Doniek on women after mastectomy belonging to the "Amazon Club" [11]. In the case of patients discussed in this study the greatest diversity could be observed regarding instrumental (16.56\%) and appraisal (15.48\%) support. Based on numerous studies Salmon believes that in the case of serious somatic illnesses, such as breast cancer, patients with a higher level of support recover faster and live longer [quote behind 12]. The correlation between SOC level together with its elements and social support has been completely proved and appraisal and informational support correlated with all the subscales of sense of coherence as well as with the global SOC. The reason for this could be the fact that the higher the level of comprehensibility, manageability, meaningfulness, and global SOC, the higher was perception of appraisal and informational support. This could also be supported by the relationship between meaningfulness and emotional support (the higher the level of meaningfulness, the greater the emotional support), or between manageability and instrumental support (people with a high level of manageability received little instrumental support). In their works Sandén-Eriksson demonstrated that a high level of SOC helps patients control chronic disease and the support given to them should increase their capabilities [13]. Sarason claims that people who believe their abilities to receive social support to be low tend to demonstrate inadequate behaviour in stressful situations. Social support is crucial regarding actions aiming at recovery from the disease and regaining health [12]. Thanks to the study it could be determined that there are certain socio-demographic variables, such as marital status, education, place of residence, and living conditions, that influence the SOC level and the social support received by women after mastectomy. A given marital status differentiated emotional support. Surprisingly enough, women who were not in any kind of relationships, namely widows or divorcees, received greater emotional support from their environment than any other group of women. Education turned out to be a factor differentiating meaningfulness and appraisal and informational support. People with the lowest degree of education demonstrated a significantly higher level of meaningfulness than other women. At the same time they received a lower level of appraisal and informational support, which was probably connected with the ability to assimilate general knowledge. Living in towns or villages of various sizes differentiated the level of manageability as well as emotional and instrumental support. Women living in larger cities and in the country had a relatively high level of manageability, i.e. they did not feel helpless in the face of the existing situation and they were able to overcome difficulties resulting from breast amputation. Women living in larger cities, however, received the lowest level of emotional support, which is perhaps related to wrong estimation of the most important life priorities. Women living in the country received the lowest degree of instrumental support. Living with various people was a factor differentiating manageability, meaningfulness and global SOC level. Depending on the place the women lived, the level of these aspects varied. Level of SOC and social support was not influenced by age of the respondents. There was no relation between SOC and age observed in the studies conducted by Szymczak, who studied sense of coherence and styles of coping with cancer and adaptation after hysterectomy [14]. SOC and social support were clearly differentiated by intermediary variables connected with cancer suffered by women who underwent breast amputation. These variables include: duration of the disease, additional treatment used (radiotherapy), physical discomfort after mastectomy, problems connected with intimate life, sense of self-esteem, selfacceptance, fear related to the possibility of recurrence of the disease, attitude of the family, friends and neighbours towards the patients, as well as possibility of appointments with psychologists and support groups ("Amazon Club"). According to Mika, uncertainty regarding effectiveness of treatment, physical impairment due to surgery and difficult personal and family problems had a direct influence on mental condition of the respondents in whom the fear of death and disability dominated [15]. Significance of positive shaping of attitudes towards disease in women after mastectomy was demonstrated by Kowalewska in her studies, the subject of which was the influence of the "Amazon Club" (support group) on self-acceptance with reference to the disease [16]. Kwaśniewska points out that in crisis there is a tendency of giving and receiving support primarily from the close family, and then from friends [17]. In this study a similar tendency could also be observed. The results of the study prove the assumptions of the salutogenic theory that states that a low level of SOC is characteristic for people suffering from chronic diseases, especially for those suffering from cancer and therefore living in constant uncertainty as to the further development of the disease. Low level of SOC in women after mastectomy was an exponent of limited capability of coping with cancer; therefore steps should be taken to strengthen global life orientation through health education planned individually for each patient with special care paid to a holistic approach towards each patient. Education would also play the role of support regarding 
releasing the ability to cope with problems of everyday life. The study also shows that social support given to women after mastectomy can be an indicator in the return to optimal health.

\section{Conclusions}

1. Women after mastectomy varied in the level of manageability and meaningfulness as well as appraisal and instrumental support. The average level of global SOC was reduced (117.19) and it was similar to that demonstrated by people in whom cancer was diagnosed. The level of informational and emotional support they received was the highest.

2. Appraisal and informational support correlated with all the subscales of SOC as well as with global SOC. The higher the level of comprehensiveness, manageability, meaningfulness or global SOC, the higher was the perception of appraisal and emotional support. Emotional support however was strictly connected with meaningfulness (the higher the meaningfulness, the greater the emotional support). Instrumental support was strictly related to manageability, whereas it formed an opposite relationship with meaningfulness. This may mean that people with a lower level of meaningfulness experienced a higher level of instrumental support.

\section{References}

1. Kordek R, Jassema J, Krzakowski M, Jeziorski A. Onkologia. Poradnik dla studentów medycyny. $\alpha$-Medica Press. Gdańsk 2003; 15-8.

2. Sheridan Ch, Radmacher S. Psychologia zdrowia. IPZ PTP. Warszawa 1998; 77-80.

3. Antonovsky A. Rozwikłanie tajemnicy zdrowia. Jak radzić sobie ze stresem i nie zachorować. Fundacja IPN, Warszawa 1995; 17-9.

4. Kurowska K. Rola poczucia koherencji i zachowań zdrowotnych u przewlekle chorych. Zdrowie Publiczne. 2005; 115: 385-90.

5. Basińska B. Radzenie sobie z konfrontacją stresową a kontinuum zdrowie - choroba nowotworowa. Psychoonkologia 2001; 8: 25-33.

6. Skokowski J, Szymczak J. Poczucie koherencji a lęk u chorych na nowotwór płuc oczekujących na operację i u osób zdrowych. Psychoonkologia 1999; 4: 35-45.

7. Tuszewska M, Tuszewski B, Stachowiak C. Jakość życia i poczucie koherencji u chorych na wrzodziejące zapalenie jelita grubego. Nowiny Lekarski 2002; 4-5: 207-211.

8. Kozak J. Jakość życia a poczucie koherencji kobiet chorych na raka jajnika. Psychoonkologia 2002; 6: 1-25.

9. Sęk H, Cieślak R. Wsparcie społeczne - stres i zdrowie. Wyd. Naukowe PWN. Warszawa 2006; 11-29.

10. Wojtyna E, Dosiak M, Życińska J. Wpływ wsparcia społecznego na przebieg zaburzeń depresyjnych u pacjentów w podeszłym wieku. Psychogeriatria Polska 2007; 4: 17-26.

11. Dońka K, Karadys K, Lewicka M, Baran D. Zapotrzebowanie na wspar cie ze strony personelu medycznego przez kobiety leczone z powodu nowotworu piersi. Wydział Pielęgniarstwa i Nauk o Zdrowiu AM w Lublinie 2007; 3-56.

12. Chodkiewicz J. Zmagając się ze światem. Znaczenie zasobów osobistych. Psychologia w medycynie. Gdańskie Wydawnictwo Psychologiczne, Gdańsk 2002; 12-34.

13. Sandén-Eriksson B. Coping with type-2 diabetes: the role of sense of coherence compared with active management. J Adv Nurs 2000; 31: 1393-401.

14. Szymczak J, Tartas M. Poczucie koherencji w chorobienowotworowej, style radzenia a adaptacja po zabiegu histerektomi. Psychiatria Pol ska 2002; 36: 759-70.

15. Mika K. Po odjęciu piersi. PZWL, Warszawa 1999; 22.
16. Kowalewska M, Kościńska. Klub „Amazonek” jako grupa wsparcia pacjentek po mastektomii. Kawczyńska-Butrym Z (ed.). Centrum Metodyczne Doskonalenia Nauczycieli Średniego Szkolenia Medycznego. Warszawa 1994; 23-44.

17. Kwaśniewska G, Wojnarska A. Aktualne problemy wsparcia społecznego osób niepełnosprawnych. Wydawnictwo Uniwersytetu M. Curie-Skłodowskiej, Lublin 2004; 290.

\section{Address for correspondence}

Krystyna Kurowska MD, Phd assistant professor Katedra i Zakład Pedagogiki i Dydaktyki Pielęgniarskiej Collegium Medicum w Bydgoszczy, UMK Toruń

ul. Techników 3

85-801 Bydgoszcz

tel. +48525852194

e-mail: krystyna_kurowska@op.pl 